\title{
On The Regrettable Decline of Law French: Or Shapiro Jettet Le Brickbat
}

\section{Martin Shapirot}

Whenever a distinguished scholar prescribes a new scholarly endeavor, we must imagine it as practiced not by him alone but by the academic multitudes and thus in its most vulgarized form. What follows is unashamedly worst-case analysis, but-present precincts excepted of course-the worst case is often enough the real case. It may be particularly unfair to subject Professor Stone's paper to this sort of analysis, in part because his own past work is in such excellent contrast to the tendencies I am about to denounce and in part because he himself sees the dangers and repeatedly warns against them. Against such considerations, however, must be counterbalanced the finding of so many of the participants in this symposium that, no matter what the signals offered by the intellectual leadership, the bulk of legal scholarship continues to focus on routine doctrinal analysis. Perhaps a handful of particularly subtle minds will be able to practice the sensitivity to language for which Professor Stone calls without falling into arid self-contemplation, but I am more concerned with the place his paper will take in the overall movement of academic legal writing.

Professor Stone's call for "law as a language" may well be the first trumpet call of an essentially reactionary movement in legal scholarship, a retreat into the bowels of law from the various law and movements. Lawyers see the stream of law and sociology, law and politics, law and economics, law and psychology as fragmenting their scholarly core and corps. They do not want to bother mastering one and after another. They may not see great payoffs in the past ands. Here they are wrong, but the payoffs often have not been as great as the pioneering zealots have promised. In some instances, such as law and politics, the internalization of the and has been so great that the legal scholars have almost forgotten that it was an alien force they were absorbing. ${ }^{1}$

+ Professor of Law, University of California at Berkeley.

1. Compare Deutsch, Neutrality, Legitimacy, and the Supreme Court: Some Intersections between Law and Political Science, 20 Stan. L. REv. 169 (1968) (treating political 


\section{Comment on Stone}

The great monument to this resistance to law and is the continuity of structure and staffing of the American law school. Of course, the avant garde of the academy make a great to-do about the scatter of curriculum innovations and the dusting of social science faculty members. The contrast with medical schools, however, remains striking. Medical schools require their students to enter with extensive undergraduate preparation in the sciences on which medicine depends and, in spite of the ideological inroads of the 70s, cram two more years of science into them before doing much about medicine itself. The law schools still require nothing of their entrants and still teach them nothing but law, albeit law with an occasional incursion of something else.

Over and above the context of fatigue and stasis in which it is offered, the prescription of law as language may turn out to be reactionary in a far more fundamental sense. It has always been easier to deal with law as a closed system of concepts than as a real world set of behaviors. All the law and movements seek to treat law as a combination of the two. The law as language movement on the other hand is to be seen as a means of abstracting from the world as it exists. It is an assertion that the proper study of legal scholars is that most internal part of the law itself, the language of the law, a language seen as separate and peculiar, and one in which the scholar's task is to polish up the concepts and vocabulary until the language seems beautiful to the native speakers.

The laws as language approach may mask its retreat to formalism by appearing itself to be the latest of the law and movements, law and language, and thus also to be looking outward as well as inward. The turn toward language, however, moves law to precisely that area where the most subtle and slippery relation exists between conceptualization and the study of behavior. For the study of language can either be the study of language behavior-how specified speaker $\mathbf{X}$ communicates with specified listener $\mathrm{Y}$-or it can be the study of how "we" speak. Once real speech of real speakers to real listeners is transformed into abstracted speech of universal speakers to universal audiences, the study of language turns into the clarification of words and concepts in the abstract or in prototypic contexts. Once law and lan-

science as subject independent of law) with J. Ely, Democracy and Distrust (1980) (analyzing judicial review from perspective combining law and political science), Schuck, The Graying of Civil Rights Law: The Age Discrimination Act of 1975, 89 YALE L.J. 27 (1979) (examining nondiscrimination statute from same perspective), Stewart, The Reformation of American Administrative Law, 88 Hakv. L. REv. 1667 (1975) (analyzing administrative law developments from same perspective). 
guage begins to deal with what "we lawyers" say, it will easily slip down the slope into treating law as an independent, closed conceptual system. Law as language is aimed principally at reasserting the autonomy of law-at returning law to lawyers by claiming that law is a specialized language that only lawyers can speak. It is indicative that Stone turns to musical notation and mathematics, esoteric languages that allow their masters to claim that others cannot understand, let alone contribute to, their disciplines.

The suspicion that Stone is in reactionary retreat rather than advancing in new directions is heightened by the tone of Section VI. ${ }^{2}$ Law is to examine its own navel carefully to see how its use of words varies-but only a bit and only subtly-from common English. In the process it will achieve waivering conclusions comparable to those in ethics and aesthetics. Law, aesthetics, and ethics are to exploit "the mutuality of our ignorance" to search out common "fundamental principles." Is this more than a prologue to yet another round in the endless search for the holy grail of neutral principles or reasoned elaboration or the law working itself clear? In lesser hands than Stone's, won't all this be a return to the jurisprudence of concepts? Will legal aesthetics be any different from the old German "legal science" except for allowing the ideological preferences behind the wordplay to show more clearly?

Is Professor Stone's paper a retreat to formalism followed by the promise that formalism can be just as good a tool for a new social democratic ideology as it was for the old liberal democratic ideology? I believe that there is a way of turning the law as language movement in a better direction. As I have just suggested, to begin with the question "what do we lawyers mean when we say 'the average reasonable man'?" is to court disaster: a barren exercise in analytic philosophy, Perelmanian rhetoric, or 1940s semantics that will lead only to the insight that lawyers don't talk exactly as other people and on the other hand they don't talk so differently either. If we begin instead by asking why a lawyer occupying a specific position (plaintiff's tort lawyer, trial judge, insurance company claims adjuster) uses the term "average reasonable man" when speaking to a specific audience (individual lay client, opposing counsel, judge, corporate client's in-house counsel, jury) in a particular setting (office conversation, appellate brief, letter stating claim, letter threatening suit, law review article), then law-as-language studies may help us to gain new

2. Stone, From a Language Perspective, 90 YALE L.J. 1149, 1168.73 (1981). 
insights about the real world and insights that allow us to describe the real world more precisely. I believe that it is far more possible to describe the real world precisely than to describe legal language precisely, if we mean by legal language some general linguistic system. It is far easier to describe legal language in a new but vague way, however, than it is to describe the real world precisely. That is the pitfall in the Stone approach: its most probable consequence is the easy way out-more law jaw-jaw-rather than the harder but more useful way out-specific description of actual language behavior.

In short, I believe that law should not now make a last start down the high road of modern linguistic philosophy-which is probably not going anywhere anyway-but ought to start down the low road of pragmatics or semiotics or communications theory, or whatever you want to call the study of language in specific context. This context has (1) a specific pre-existing situation, (2) a specific sender, (3) a specific transmission medium, (4) a specific receiver, (5) a specific change in the pre-existing situation subsequent to the transmission. The low road would quickly lead us to (1) a new perspective, (2) a new body of data, and (3) new analytical tools.

(1) We have both deliberately and unconsciously treated law talk as the talk of judges to other judges and to lawyers contemplating future litigation (case method, stare decisis). But the two principal talks of lawyers are lawyer to client (counseling) and lawyer to lawyer (negotiating). We have assumed without empirical investigation that these two talks are so heavily determined by judge to judge and judge to lawyer talk that we may study the case law tail rather than the counseling and negotiating dog. What if we began our study of law with the proposition that law is not what judges say in the reports but what lawyers say-to one another and to clients-in their offices?

(2) What if our data were not the reports but office files?

(3) What if our tool was the historical reconstruction of the flow of talk rather than Lexis?

Such an approach would give us a more accurate description of law as it is. Would it do more: would it give us a tool for making law "better" in some sense? Yes, because it would allow us to spot failures of communications and so lead to the improvement of communications technique. More important, it would allow us to see where legal conflict or misunderstanding was a result of inadequate communication and where it was a result of differing purposes in different categories of senders and receivers. 
My disagreements with (or perhaps only differences of emphasis from) Stone can be seen in the following diagramatic pastiche which, for the sake of completeness, also charts a middle road about which I know too little to comment. The difficulty with talking about law as language or even law and language is that it lumps together all the various paths so roughly sketched here. I accuse Professor Stone first of trying to reestablish the autonomy of legal discourse-law as its own language rather than law and everybody's language-and second of taking the high road on my sketch map while I take the low.

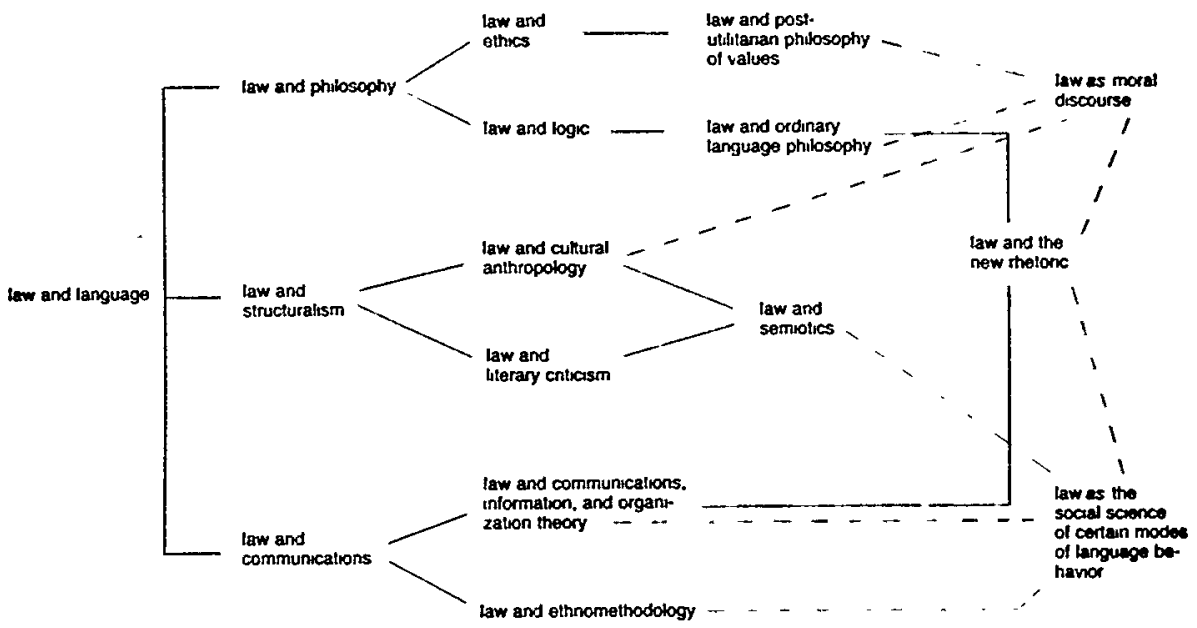

There are hints that Stone might be willing to head down the communications theory and ethno-methodology paths. His concentric circle image $^{3}$ appears to me ambivalent, on the one hand implicating practical and specific language behavior in the realm of legal scholarship, on the other reserving the central place of honor for abstract law-language analysis. If, however, he is in fact urging law and philosophy, then, as he himself repeatedly suggests, he is choosing an uncertain way. Ordinary language philosophy is already chasing its own tail. As to the new ethics, the lawyer's wish is father to the belief that it will get very far. The building of a post-consequentialist ethics is still at a rudimentary and confused stage, ${ }^{4}$ and, as a number of the contributors to this symposium argue, such an ethics will prob-

3. See id. at 1173-79.

4. See Barry, And Who Is my Neighbor? 88 YALE L.J. 629, 690-34 (1979) (reviewing C. Fried, Right ANd Wrong (1977)) (paradigm of moral philosophy to succeed consequentialism not yet fully formed). 
ably be unable to provide a fully satisfactory moral justification for the liberal democratic state of which our law is a part.

I believe that Stone's preferred path actually lies along the lines to moral discourse and that he is really part of the new jurisprudence of values that we have already seen taking shape in legal and political theory, ${ }^{5}$ in constitutional law, ${ }^{8}$ and in the attacks on law and economics. ${ }^{7}$

This new jurisprudence of values has been generated in part by developments in philosophy but in far greater part by the renewed self-confidence of lawyers. Chastised by the New Deal and its realist fellow travelers, lawyers and judges had subsided into subordination to the demos. Revived by their singular success at exploiting the political structures of the 1950s, 60s, and 70s, and having become leaders of an elite, antidemocratic intellectual stratum bent on forcing equality and other virtues down the throats of the booboisie, lawyers and judges now commission the academy to tell us that they can correct the faults of a decadent polyarchy. At their most modest, the new scholars tell us that lawyers and judges should engage in representation reinforcing. At their most bumptious, they tell us that if only lawyers are left free to talk to one another-that is, to litigate-then their language, properly honed of the professionals, by the professionals, and for the professionals, will produce more correct ethical judgments than the rest of us can produce by our Doolittlian jabber. ${ }^{8}$

Professor Stone's paper is, in its own terms, a call for a more sensitive, self-conscious, and objective examination of legal language than has generally occurred in the advocacy-based scholarship that has been assailed by a number of contributors to this symposium. I believe, however, that the law as language approach that he chooses will, quite contrary to his own intentions, simply contribute to the hubris of the jurisprudence-of-values movement in particular and of academic lawyers in general. For in spite of the assorted pessimisms

5. See, e.g., R. Dwokxin, Taking Rughts Serjousty (1977); C. Fried, Right and Wrong (1977); M. WalzeR, JUST ANd UNJUST WARS (1977).

6. See, e.6., B. Ackerman, Soclal Justice and the Liberal State (1980); Fiss, The Supreme Court, 1978 Term-Foreword: The Forms of Justice, 93 HaRv. L. REv. I (1979); Tribe, The Puzzling Persistence of Process-Based Constitutional Theories, 89 YALE L.J. 1063 (1980).

7. See, e.g., Fletcher, Fairness and Utility in Tort Theory, 85 HARv. L. REv. 537 (1972).

8. It is because they are feeling their own oats, but have become accustomed to the various law and movements, that academic lawyers wish to impute a similar renewed self-confidence to moral philosophers who will be towed along as footnotes to the lawyers' self-awertions of moral grandeur. 
and self-doubts expressed in this symposium by Professors Brest ${ }^{9}$ and Tushnet, ${ }^{10}$ law and philosophy will be the high road to assertions of the moral and intellectual, and thus political, superiority of lawyers. I must conclude that some twenty years hence when the Yale Law Journal again has the temerity to hold a conference on legal scholarship, we shall have the new Cokes speaking, as Stone already does, of the artificial reason of the law, and that at the third such conference we shall be more than ready for the new Benthams.

9. See Brest, The Fundamental Rights Controversy: The Essential Contradictions of Normative Constitutional Scholarship, 90 YALE L.J. 1063, 1106.09 (1981).

10. See Tushnet, Legal Scholarship: Its Causes and Cure, 90 YALE L.J. 1205, 1223 (1981). 